\title{
Chemomodulatory Potential of Bartogenic Acid Against DMBA/Croton Oil Induced Two-Step Skin Carcinogenesis in Mice
}

\author{
Chandragouda R. Patil $1^{*}$, Bhavin M. Sonara $1^{*}$, Umesh B. Mahajan ${ }^{*}$, Kalpesh R. Patil2, Dipak D. Patil ${ }^{3}$, \\ Ramchandra B. Jadhav ${ }^{4}$, Sameer N. Goyal ${ }^{1 凶}$, Shreesh Ojha ${ }^{5 凶}$ \\ 1. Department of Pharmacology R. C. Patel Institute of Pharmaceutical Education and Research, Shirpur 425405, Maharashtra, India; \\ 2. Department of Pharmacology, H. R. Patel Institute of Pharmaceutical Education and Research, Shirpur 425405, Maharashtra, India; \\ 3. Department of Pharmaceutical Chemistry, H. R. Patel Institute of Pharmaceutical Education and Research, Shirpur 425405, Maharashtra, India; \\ 4. Department of Pharmacognosy, R. C. Patel Institute of Pharmaceutical Education and Research, Shirpur 425405, Maharashtra, India; \\ 5. Department of Pharmacology and Therapeutics, College of Medicine and Health Sciences, United Arab Emirates University, PO Box-17666, Al Ain, Abu Dhabi, UAE. \\ *Authors contribute equally to this work.
}

$\triangle$ Corresponding authors: Dr. ShreeshOjha, Department of Pharmacology and Therapeutics, College of Medicine and Health Sciences, United Arab Emirates University, P.O.Box 17666, Al-Ain, United Arab Emirates, Tel: +971-3-7137524, E-mail: shreeshojha@uaeu.ac.ae \& Dr. Sameer N. Goyal, Department of Pharmacology, R. C. Patel Institute of Pharmaceutical Education and Research, Shirpur 425405, Maharashtra, India, Tel: +91-9552916993; Fax: +91-2563-251808, Email: goyal.aiims@gmail.com

(c) Ivyspring International Publisher. Reproduction is permitted for personal, noncommercial use, provided that the article is in whole, unmodified, and properly cited. See http://ivyspring.com/terms for terms and conditions.

Received: 2016.06.11; Accepted: 2016.08.14; Published: 2016.10.23

\begin{abstract}
Barringtonia racemosa fruits are believed to be useful in cancer treatment in Ayurveda, the Indian system of medicine. In present study, bartogenic acid (BA), a triterpenoid constituent of Barringtonia fruits was evaluated for its cytotoxicity property using the human skin carcinoma cell line (SCC-13) and human peripheral blood mononuclear cells (PBMC). The chemopreventive efficacy of BA was evaluated against the DMBA/Croton oil-induced skin carcinogenesis in mice.BA was orally administered at the doses of 1 , 2 or $4 \mathrm{mg} / \mathrm{kg} /$ day or applied topically every day for 12 weeks following DMBA application. The in vitro data from cell lines revealed that BA induces cytotoxicity against the SCC- 13 cells $\left(I_{50}=7.5 \mu M\right)$. It was found 4.05 times more selective to exert cytotoxicity against SCC-13 as compared to the PBMC $\left(\mathrm{IC}_{50}=30.4 \mu \mathrm{M}\right)$. The in vivo datacollected from mice model of DMBA/Croton oil-induced skin carcinogenesis revealed that BA administered orally or applied topically, both reduced the precancerous skin lesions andthe incidence of tumor bearing. The oral doses of BA ( 2 and $4 \mathrm{mg} / \mathrm{kg})$ and topical treatment significantly reduced the incidence and number of skin papillomas. At these doses, BA also increased the activities of catalase and superoxide dismutase and induced an increase in glutathionecontent and inhibited lipid peroxidation in the skin. These findings reveal the chemopreventive efficacy of BA and also demonstrate that it contributes to the cytotoxic and antioxidative effects of Barringtonia racemosa fruits. The study also validates the traditional claims of Barringtonia fruits and provides a scientific basis of its chemopreventive property.
\end{abstract}

Key words: Bartogenic acid, Two-stage skin carcinogenesis, DMBA/Croton oil, Skin Cancer, Chemoprevention, Natural products, Phytochemicals.

\section{Introduction}

Cancer is the second foremost non-communicable disease subsequent to the cardiovascular diseases and emerged as a serious illness worldwide. Parallel to the rising epidemic in developed world, cancer is one among the highly rising diseases in developing countries including India [1]. The cause of majority of the cancers are genetic predisposition and exposure to the environmental pollutants such as excessive tobacco or alcohol, exposure to harmful chemicals and radiations [2], which leads to either internal factors such as spontaneous mutations, hormones and nutrient metabolism in the body or by external stimulators [3]. Among different types of cancers, skin cancer is one of 
the most common forms of human cancer [4]. Every year almost around 1.2 million new skin cancer cases are diagnosed in the United States [5].

The animal models used to recapitulate human skin cancer are based on the induction of skin cancer by several environmental chemicals. One of the potent skin carcinogen is 7,12-Dimethylbenzene[a] anthracene (DMBA) that is routinely employed in preclinical studies for understanding the pathogenesis of skin cancer and evaluation of novel therapeutic agents. Repeated topical exposures to DMBA along with a promoter agent like croton oil lead to the development of skin tumors [6]. This two stage skin carcinogenesis model is considered a suitable model to evaluate the effect of test drugs on the tumor growth at different stages of its induction and progression [7].

Barringtonia racemosa Roxb. (Lecythidaceae) is widely reported to possess anticancer and chemopreventive properties. The methanolic extract of seeds of Barringtonia racemosa administered intraperitoneally at the dose of $6 \mathrm{mg} / \mathrm{kg}$ showed to prevent the Dalton's lymphoma ascetic tumors in mice. However, the constituents responsible for such potent antitumor property remain unidentified and unknown [8]. The ethanolic extract of leaves of this plant showed cytotoxic activity against HeLa cell line [9]. The fruits of $B$. racemosa are widely used by some tribes in India for the treatment of tumors [8]. The fruits are reported to possess multiple activities including anti-inflammatory, anti-nociceptive, anti-oxidant, cytotoxic, antifungal and antibacterial [10]. A prior investigation carried out by us revealed that the BA, a principal component of $B$. racemosa possesses potent immunosuppressant and antiarthritic activities [11]. The present study was aimed to investigate the chemopreventive potential of BA in vitro using human skin carcinoma cell line (SCC-13) and human peripheral blood mononuclear cells (PBMC). Further, the chemopreventive efficacy of BA was evaluated in vivo using mice model of DMBA/Croton oil-induced two-stage skin carcinogenesis.

\section{Materials and methods}

\section{Chemicals}

Bartogenic acid (Catalogue number: 79355-89-8) was procured from Gamay Industrial Technology Co. Ltd., China. DMBA, Croton oil, 5, 5'-dithiobis-2-nitrobenzoic acid (DTNB), glutathione (GSH),superoxide dismutase, catalase, NADPH (nicotinamide adenine dinucleotide phosphate, pyrogallol, thiobarbituric acid (TBA), bovine serum albumin (BSA) were procured from Sigma Chemicals,
MO, USA. All the other chemicals used were of analytical grade.

\section{Experimental animals}

Swiss albino mice (23-25 gm, 6-8 weeks) were obtained from National Institute of Nutrition, Hyderabad, India and housed in cages. The animals were acclimatized for one week prior to the start of the experiment. The animals were kept housed in climate controlled facility at standard laboratory conditions such as temperature $24 \pm 2^{\circ} \mathrm{C}$, humidity $55 \pm 5 \%$, with a photoperiod of $12 \mathrm{~h}$ light/12 h dark cycle. They were provided water ad libitum and all time access to the pellet diet available commercially available from Amrut feed, Pune, India. The experiments were performed in accordance to the experimental protocol approved by the Institutional Animal Ethical Committee (Protocol approval no. RCPIPER/CPCSEA/2010-11/9) that confirms to the guidelines of Committee for the Purpose of Control and Supervision of Experiments on Animals (CPCSEA), Ministry of Environment, Government of India, India.

\section{Experimental design}

For this study, the mice which were the resting phase of the hair cycle were divided into six groups, each containing 12 mice. These groups were assigned to different treatments as follows:

Group I (Control): This group of animals served as vehicle control received topical application of acetone $(100 \mu \mathrm{L} /$ mouse $)$ on the shaved area of the skin and $0.5 \%$ Tween $80 \quad(10 \quad \mathrm{ml} / \mathrm{kg})$ by intragastricgavage for 12 weeks.

Group II (DMBA/Croton oil applied): The animals in this group received topical applications of DMBA at an interval of 72 hours at a dose of $0.05 \mathrm{~g} / \mathrm{kg}$ in acetone $(100 \mu \mathrm{L} /$ mouse $)$. Starting from the eight days after first DMBA application, croton oil $(1 \%$ $\mathrm{w} / \mathrm{v})$ in acetone $(100 \mu \mathrm{L} /$ mouse) was applied twice in a week for a total of 12 weeks, as described previously by Qiblawi, Al-Hazimi [12].

Group III (Treated with BA orally): The animals in this group were applied with DMBA/Croton oil similar to group-II following concomitant treatment with BA administered orally using intragastric gavage at three doses; $1 \mathrm{mg} / \mathrm{kg}$ (Group III), $2 \mathrm{mg} / \mathrm{kg}$ (Group IV) and $4 \mathrm{mg} / \mathrm{kg}$ (Group V) respectively for 15 days before the first DMBA application and continued up to 12 weeks after DMBA application.

Group VI (Treated with BA topically): The animals in this group were applied with DMBA/Croton oil similar to DMBA/Croton oil-treated group along with topical application of BA at a dose of $4 \mathrm{mg} / \mathrm{kg}$ prepared with $100 \mu \mathrm{L}$ of $0.05 \%$ 
Tween-80 for 15 days before the first DMBA application and continued for 12 weeks after DMBA application.

During the 12 weeks of experimental period, the animals were observed daily for the appearance of skin papillomas and the tumor volume was recorded. At the end of 12 weeks, all the mice were sacrificed and the skin samples were collected.

\section{Evaluation of parameters}

In vitro cytotoxic efficacy of BA on SCC13 and PBMC cell lines

\section{Cell Culture}

The SCC13 cells were procured from ATCC (Manassas, VA) and human PBMC isolated by density centrifugation of heparinized blood of healthy donors using dextran T-500 sedimentation method [13]. The cells were grown adherently in RPMI-1640 media supplemented with $10 \%$ fetal calf serum, $100 \mathrm{U} / \mathrm{mL}$ penicillin and $100 \mu \mathrm{g} / \mathrm{mL}$ streptomycin at $37^{\circ} \mathrm{C}$ in $5 \%$ $\mathrm{CO}_{2} / 95 \%$ air.

\section{Cell Viability Assay}

The viability of the cells were determined using 3-(4,5-dimethylthiazol-2-yl)-2, 5-diphenyltetrazolium bromide (MTT) assay. The SCC13 and PBMC cells were seeded at $5 \times 10^{3}$ cells/well in $5 \% \mathrm{CO}_{2}$ at $37^{\circ} \mathrm{C}$ in RPMI medium (containing 10\% FBS, 100 units/mL penicillin and $100 \mu \mathrm{g} / \mathrm{mL}$ of streptomycin) in 96-well plate. After overnight incubation to allow cell attachment, the RPMI medium in each well was replaced by media containing various concentrations of BA and incubated for 48 hours. Further, 20 $\mu 1$ of MTT (5 mg/mL in PBS) was added to each well and the cells were incubated for another 4 hours at $37^{\circ} \mathrm{C}$. The supernatants were then aspirated carefully and $200 \mu \mathrm{L}$ of dimethyl sulfoxide was added to each well of the microplate. The plates were shaken for an additional $10 \mathrm{~min}$ and the absorbance values were read by the Microplate reader (BioTek, USA) at 570 $\mathrm{nm}$. Cell viability was calculated as a percentage using the formula: (mean OD of treated cells/mean OD of control cells) $\times 100$. The results were expressed as percent of control or normal cells.

Determination of the in vivo chemomodulatory efficacy of $\mathrm{BA}$ on DMBA/Croton oil induced skin carcinogenesis

For determining the in-vivo chemomodulatory efficacy of BA on DMBA/Croton oil induced skin carcinogenesis following parameters were used.

\section{Morphological examination of tumor}

\section{Measurement of body weight}

The body weight of the individual mouse was recorded initially and at one week intervals till the end of experiment or death of the mouse.

\section{Tumor incidence}

The number of mice carrying at least one tumor was expressed as a percentage incidence.

\section{Tumor burden}

The average number of tumors per tumor-bearing mouse was assessed.

\section{Cumulative number of tumors}

The total number of tumors seemed till the end of the experiment protocol were estimated.

\section{Tumor diameter and tumor volume}

The tumor diameters across three dimensions were measured using a Mututoyo Digimatic caliper (model 500-196-20). The tumor volume was calculated by the formula Volume $=(4 / 3) \Pi$ [D1/2][D2/2][D3/2], where D1, D2 and D3 are the three diameters $(\mathrm{mm})$ of the tumors [5].

\section{Tumor weight}

The weight of each tumor was measured at the termination of study protocol. At the end of 12 weeks post DMBA application, the mice were sacrificed. The skin samples from each mouse were processed.

\section{Estimation of oxidative injury using skin tissue homogenate}

The skin tissue was separated and washed several times in an ice-cold saline. The skin tissue (100 $\mathrm{mg}$ ) was carefully chopped into fine pieces using the surgical blade. The minced skin tissue was homogenized in an ice-cold phosphate buffer ( $\mathrm{pH}$ 7.4) with help of a homogenizer (RQ127A/D, Remi, Maharashtra, India). Typically, the homogenizer was set at a speed of $1000 \mathrm{rpm}, 10$ strokes for $30 \mathrm{sec}$ for 2-3 times at $4^{\circ} \mathrm{C}$ were applied to get a complete homogenate of the skin tissue. The resultant homogenate was centrifuged at $20000 \mathrm{rpm}$ for $5 \mathrm{~min}$ at $4^{\circ} \mathrm{C}$. The tissue debris was separated as a pellet and the supernatant was pipette out. The skin tissue homogenate was stored at $-20^{\circ} \mathrm{C}$ until further use. The aliquot of the homogenate prepared in chilled conditions was used to estimate the biochemical parameters.

\section{Estimation of glutathione (GSH)}

The GSH contents in the skin tissues were estimated by the method of Majed et al. (2015) [14]. Briefly, $100 \mu l$ of tissue homogenate was mixed with $100 \mu \mathrm{l}$ of $10 \%$ trichloro acetic acid and vortexed. The contents were then centrifuged at $5000 \mathrm{rpm}$ for 10 min. Subsequently $0.05 \mathrm{ml}$ of supernatant was mixed 
with a reaction mixture containing $3.0 \mathrm{ml}$ of phosphate buffer ( $\mathrm{pH} 8.4,0.3 \mathrm{M}$ ) and $0.5 \mathrm{ml}$ of DTNB [5, 5' dithiobis (2-nitrobenzoic acid)]. Within $10 \mathrm{~min}$, the absorbance was measured at $412 \mathrm{~nm}$ using a spectrophotometer. The GSH content was determined from a standard curve produced using commercially available standard GSH (Sigma Chemicals, MO, USA). The amount was expressed as $\mu \mathrm{g}$ of GSH/mg of protein. In samples, the GSHPx [15] activity was measured by quantifying the rate of $\mathrm{H}_{2} \mathrm{O}_{2}$-induced oxidation of GSH to oxidized glutathione, catalyzed by glutathione peroxidase (GSHPx).

\section{Estimation of lipid peroxidation}

The level of lipid peroxidation in the skin tissue was determined by measuring the MDA content using the method described by Divya et al. 2016 [16]. Briefly, $0.2 \mathrm{ml}$ of homogenate was mixed with $0.2 \mathrm{ml}$ of sodium dodecyl sulphate $(8.1 \%), 1.5 \mathrm{ml}$ of acetic acid $(\mathrm{pH} \mathrm{3.5,30 \% )} \mathrm{and} 1.5 \mathrm{ml}$ of thiobarbituric acid $(0.8 \%)$. The reaction mixture was heated for $60 \mathrm{~min}$ at $95^{\circ} \mathrm{C}$ and then cooled on ice bath. After cooling, $1.0 \mathrm{ml}$ of distilled water and $5.0 \mathrm{ml}$ of n-butanol: pyridine $(15: 1 \mathrm{v} / \mathrm{v})$ solution were added and centrifuged at $5000 \mathrm{rpm}$ for $20 \mathrm{~min}$. The absorbance of the pink color in organic layer was measured at $532 \mathrm{~nm}$. In spectrophotometric measurement of lipid peroxidation, 1,1,3,3 tetraethoxypropane (Sigma Chemicals, MO, USA) was used as the standard MDA and levels were expressed as $\mu \mathrm{g} / \mathrm{g}$ of protein.

\section{Estimation of catalase activity}

The catalase activity was determined by the method described by Saleem et al., (2015) [17]. Briefly, to the tissue supernatant $(50 \mu \mathrm{l}), 1.0 \mathrm{ml}$ of $50 \mathrm{mM}$ phosphate buffer $(\mathrm{pH} \mathrm{7})$ and $0.1 \mathrm{ml}$ of $30 \mathrm{mM}$ hydrogen peroxide were added. The absorbance was read at $240 \mathrm{~nm}$ on every $5 \mathrm{sec}$ for $30 \mathrm{sec}$ on the spectrophotometer. The activity of catalase was expressed as $\mathrm{U} / \mathrm{mg}$ of protein.

\section{Estimation of superoxide dismutase activity}

The SOD activity was determined by the method of Sharma et al., (2015) [18] with slight modifications. Briefly, to the tissue supernatant $(100 \mu \mathrm{l}), 2.85 \mathrm{ml}$ of phosphate buffer ( $\mathrm{pH} 8.4,0.1 \mathrm{M}$ ) and $50 \mu \mathrm{l}$ of $7.5 \mathrm{mM}$ pyrogallol were added. The absorbance of the resultant mixture was measured on the spectrophotometer at $420 \mathrm{~nm}$ for $3 \mathrm{~min}$ at $30 \mathrm{sec}$ intervals. The enzyme levels were expressed as $\mathrm{U} / \mathrm{mg}$ of protein.

\section{Histological evaluation}

The skin tissues were fixed in the buffered formalin $(10 \%)$ and cut in to four segments and embedded in the paraffin wax. These formalin fixed paraffin embedded sections were cut to get the serial thin sections of $4 \mu \mathrm{m}$ thickness and subjected to the hematoxylin and eosin ( $\mathrm{H} \& \mathrm{E})$ staining protocol. These sections after H\&E stainingwere examined under the light microscope (Nikon, Tokyo, Japan) and digital images were captured. The slides were evaluated by a qualified experienced pathologist masked to the experimental groups and treatments. A minimum of 10 fields for each slide were examined and scored.

\section{Statistical analysis}

The data were expressed as mean \pm SEM and were analyzed by one way analysis of variance (ANOVA) followed by Bonferroni's multiple comparison test or Dunnette's post hoc test using the Graph Pad Prism software version 6.0. The criterion of statistical significance was set at $\mathrm{P}<0.05$.

\section{Results}

\section{In vitro cytotoxic efficacy of BA on $\mathrm{SCC13}$ and PBMC cell lines}

The cytotoxic efficacy of BA was evaluated in SCC13 and human PBMC cells using MTT assay. As depicted in figure 1 , the $\mathrm{IC}_{50}$ of $\mathrm{BA}$ for the $\mathrm{SCC} 13$ cell line and PBMC were observed to be $7.5 \mu \mathrm{M}$ and 30.4 $\mu \mathrm{M}$, respectively. The selectivity index for BA against the SCC13 cells was 4.05 .

\section{In vivo chemomodulatory efficacy of BA on DMBA/Croton oil-induced skin carcinogenesis}

\section{Effect of BA on changes in body weight}

A continuing rise in body weight after the beginning of treatment was observed in all the groups and such weight was found to be near normal at the end of the experimental period. The normal mice and the mice treated with BA do not show significant changes in body weight through the experimental protocol.

\section{Effect of BA on morphological examination of tumor}

The incidence of tumors starting from $6^{\text {th }}$ week in DMBA/Croton oil-treated animals were considered $100 \%$ and all mice in carcinogen treated group developed papillomas (100\% incidence) at the end of $12^{\text {th }}$ weeks. The oral treatment with BA at doses of 1,2 , $4 \mathrm{mg} / \mathrm{kg}$ reduced the incidence of papilloma in a dose dependent manner and incidence in these groups was calculated $89.3 \%, 52.4 \%$ and $36.1 \%$ respectively (Table 1 ). The group received BA topically at $4 \mathrm{mg} / \mathrm{kg}$ dose showed $48.2 \%$ tumor incidence (Table 1 ). 
Table 1. Effect of BA on morphological appearance of tumor.

\begin{tabular}{|c|c|c|c|c|c|}
\hline Experimental groups & $\begin{array}{l}\text { Tumor Incidence } \\
(\%)\end{array}$ & Number of tumors/mouse & Tumor volume $\left(\mathrm{mm}^{3}\right)$ & Tumor weight (gm) & Mortality \\
\hline Normal & 0 & 0 & 0 & 0 & 0 \\
\hline DMBA control & 100 & $11.07 \pm 2.49$ \#\#\# & $137.5 \pm 22.5^{\# \# \# ~}$ & $1.82 \pm 0.03^{\# \# \# ~}$ & 4 \\
\hline BA (1) & 89.3 & $9.72 \pm 2.8$ & $124.8 \pm 11.4$ & $1.01 \pm 0.01$ & 3 \\
\hline BA (2) & 52.4 & $6.34 \pm 0.9^{* * *}$ & $89.7 \pm 8.7^{\star \star *}$ & $0.61 \pm 0.01^{\text {** }}$ & 0 \\
\hline BA (4) & 36.1 & $4.19 \pm 0.93^{* \star *}$ & $45.6 \pm 9.8^{* \star *}$ & $0.11 \pm 0.01^{\star \star *}$ & 0 \\
\hline Topical & 48.2 & $8.21 \pm 3.10^{* *}$ & $63.5 \pm 18.8^{* \text { ** }}$ & $0.51 \pm 0.01^{* *}$ & 1 \\
\hline
\end{tabular}

The data were expressed as mean \pm SEM ( $n=8-12$ mice). ${ }^{* * *} \mathrm{p}<0.001$, ${ }^{* *} \mathrm{p}<0.01$ compared to DMBA/Croton oil applied mice; \#\#\# $\mathrm{p}<0.001$ compared to normal control group.

The figures in the parenthesis show dose in $\mathrm{mg} / \mathrm{kg}$ (BA: Bartogenic acid).
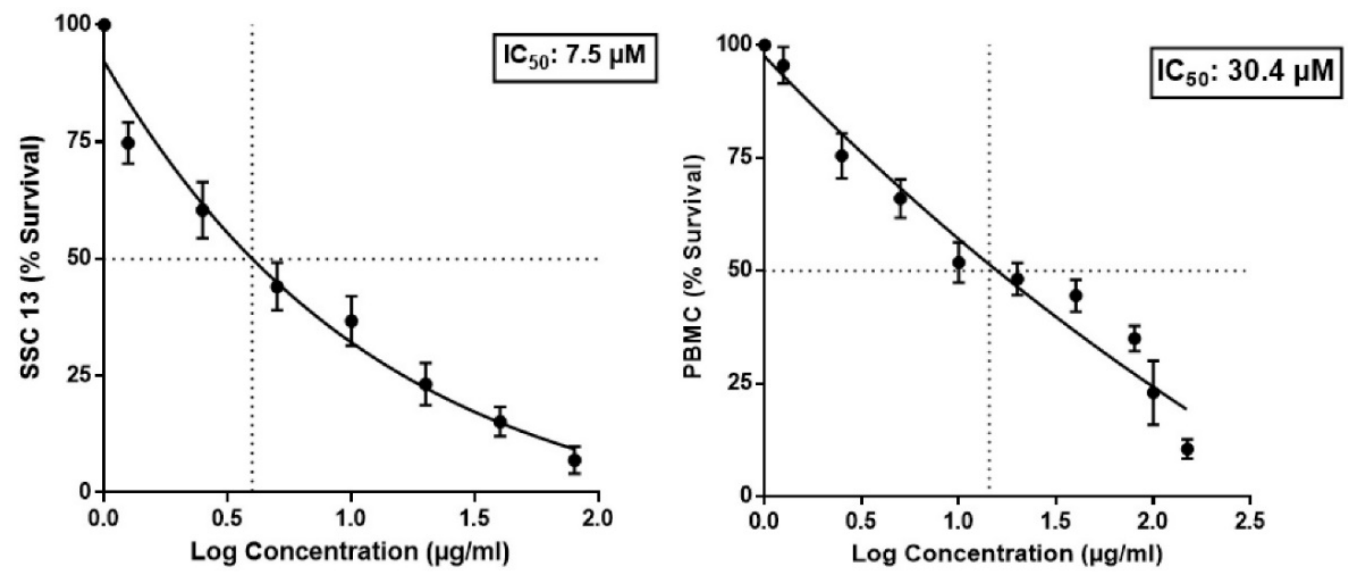

Figure 1. Effect of $\mathrm{BA}$ on $\mathrm{SCCl} 3$ and PBMC viability in MTT assay.

The cumulative number of tumors in tumor bearing mouse treated with BA showed significant decrease $(p<0.01)$ than the mice treated with DMBA/Croton oil (Table 1). The tumor volume was increased significantly $(\mathrm{p}<0.01)$ in the group applied DMBA/Croton oil than the normal group. Whereas, the groups treated with BA showed significant $(p<0.01)$ reduction in tumor volume as compared to DMBA/Croton oil applied mice (Table 1). The mice applied DMBA/Croton oil showed significant $(p<0.001)$ increase in tumor weight as compared with the normal mice. Whereas, treatment with BA showed dose dependent decrease in the weight of tumor as compared to DMBA/Croton oil applied mice (figure 1).

\section{Effect of BA on malondialdehyde content}

The level of MDA in the skin tissue homogenate of animals applied DMBA/Croton oil showed significant $(\mathrm{P}<0.01)$ increase in the level as $221.4 \pm 25.61$ with respect to vehicle control animals. The animals treated with BA at the dose of $1 \mathrm{mg} / \mathrm{kg}$ did not show significant reduction in MDA level. Whereas, BA at the dose of 2 and $4 \mathrm{mg} / \mathrm{kg}$ showed significant $(\mathrm{P}<0.01) \quad$ decrease $\quad(125.7 \pm 17.85$ and $104.5 \pm 5.4$ respectively) in the level of MDA as compared to the mice applied with DMBA/Croton oil. The mice treated topically with BA showed mild reduction in MDA level as 141.6 \pm 17.32 (figure 2).

\section{Effect of BA on oxidative stress markers}

Oxidative stress was assessed by the GSH content, and activities of GSHPx, SOD and catalase represented as markers of enzymatic and non-enzymatic antioxidant defense systems. DMBA/Croton oil induced a state of evident oxidative stress as demonstrated by a significant $(\mathrm{P}<0.01)$ decrease in GSH content $(4.01 \pm 0.80)$ and reduced activities of GSHPx (11.40 \pm 1.10$)$, SOD $(10.22 \pm 3.64)$ and catalase $(9.93 \pm 1.10)$ in a dose dependent manner in skin tissue homogenates. However, treatment with BA dose dependently ameliorated oxidative stress as evidenced by reduced depletion of GSH content and restoration of activities of GSHPx, SOD and catalase (figure 3).

\section{Effect of BA on histopathology of skin}

The animals in the vehicle treated normal group showed normal skin layers, architecture and structure such as epidermis, dermis and basal layer (Figure 4A). Carcinogen and promoter DMBA/Croton oil-induced skin cancer in mice was evidenced by the occurrence of squamous cell carcinoma, exhibited thickening of the epidermis, scratched in the layers of skin and proliferative growth of cell as observed in figure $4 \mathrm{~B}$. 
The treatment of mice with BA at the dose of 1 $\mathrm{mg} / \mathrm{kg}$ showed mild loss to epidermis and the layers of skin. Whereas, BA treatment at the doses; 2 and 4 $\mathrm{mg} / \mathrm{kg}$ showed the normal structure and architecture of skin layers and prevented further impairment to skin tissues thus reconfirming the biochemical correlates of the chemopreventive efficacy of BA.

The animals treated topically with BA at the dose of $4 \mathrm{mg} / \mathrm{kg}$ showed mild to moderate inhibition of scratched to skin layers and invasion of epidermal cells in the dermis and formation of keratin pearls as compared to the DMBA/Croton oil induced skin cancer in mice (Table 2).
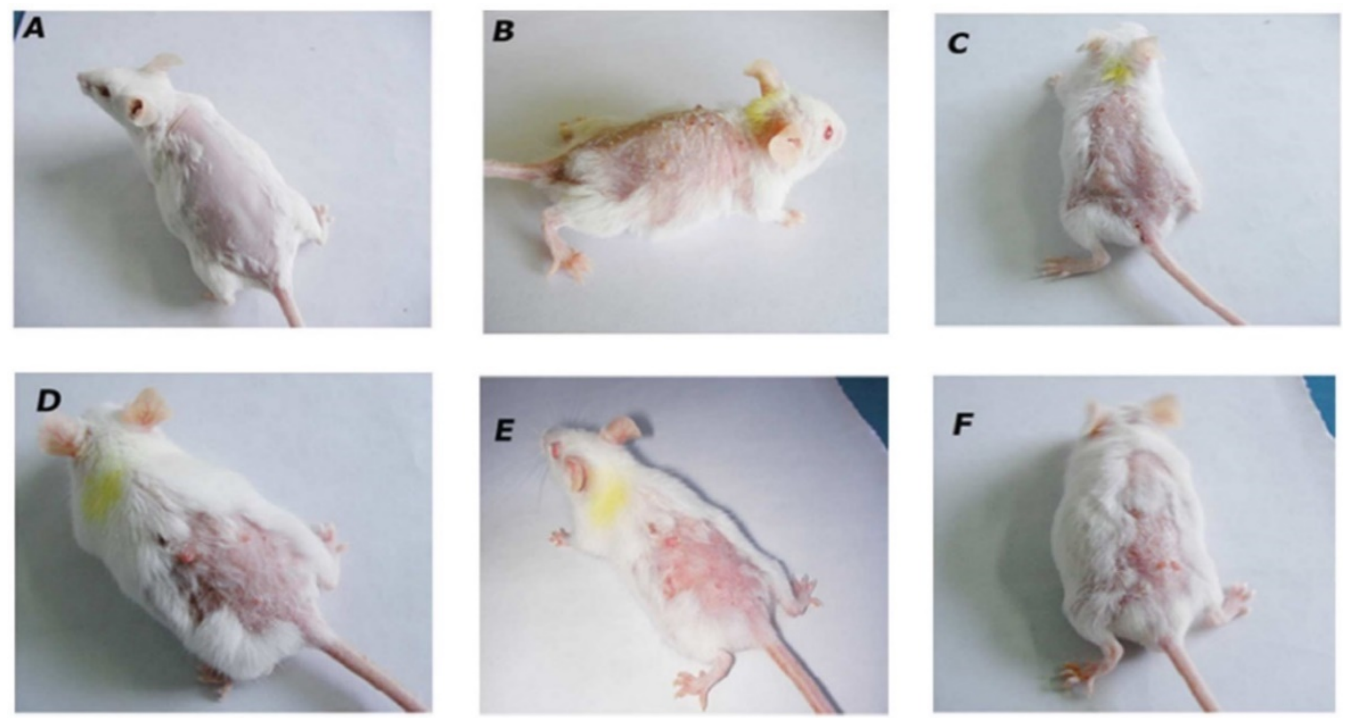

Figure 2. Effect of BA on morphological features of tumor. Morphological variations in tumor appearance during DMBA/Croton oil induced skin carcinogenesis. A: Normal control or vehicle treated mice; B: DMBA/Croton oil treated mice; C: BA (1 mg/kg p.o.); D: BA (2 mg/kg p.o.); E: BA (4 mg/kg p.o.); F: Topical BA $(4 \mathrm{mg} / \mathrm{kg})$.

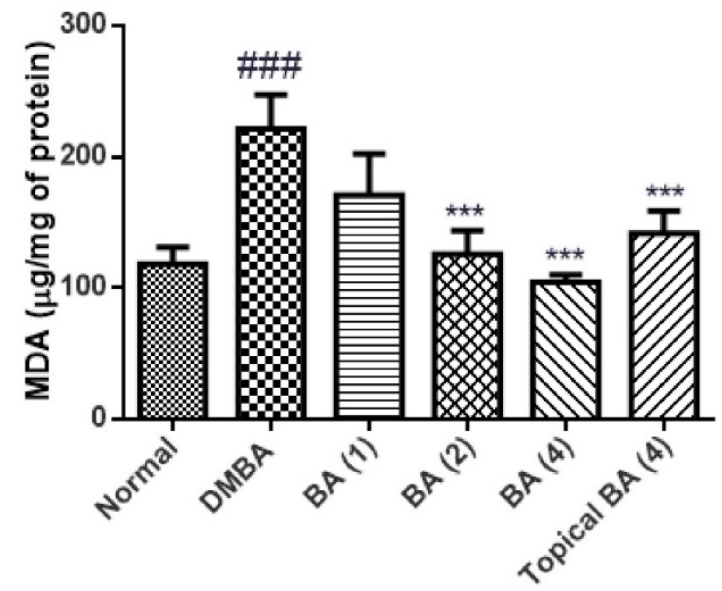

Treatment

Figure 3. Effect of BA on malondialdehyde content as lipid peroxidation. The data was expressed as mean \pm SEM. Statistical significance was determined using one-way analysis of variance (ANOVA) followed by Dunnett's post hoc test. ${ }^{\# \#} \mathrm{p}<0.001$ as compared to normal group and ${ }^{* * *}$ p $<0.001$ as compared to DMBA treated mice, BA: Bartogenic acid. The figure in the parenthesis indicates the dose in $\mathrm{mg} / \mathrm{kg}$ p.o. 

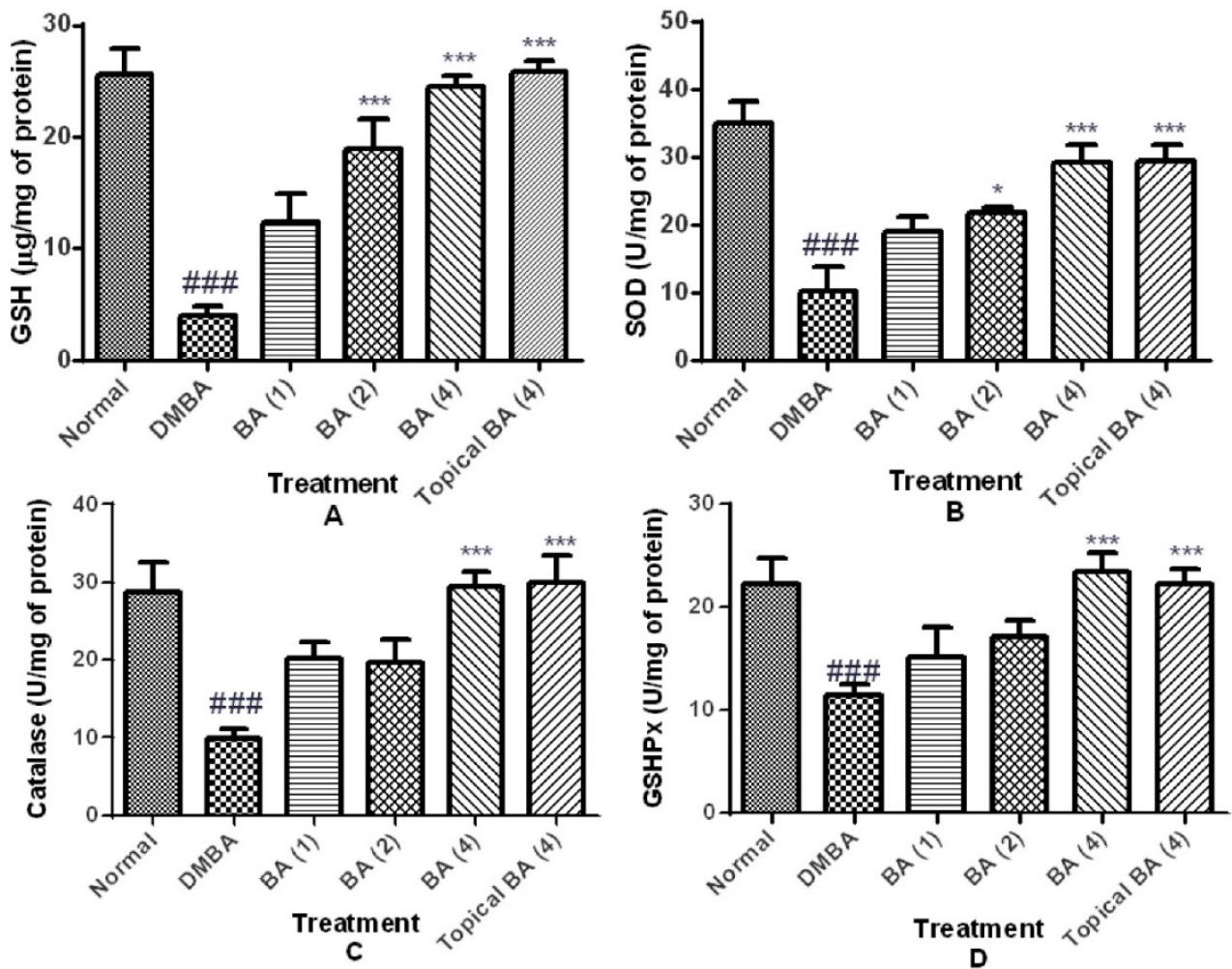

Figure 4. Effect of BA on oxidative stress markers. The data were expressed as mean $\pm S$.E.M. Statistical significance was determined using one-way analysis of variance (ANOVA) followed by Dunnett's post hoc test. $\mathrm{p}<0.001$ as compared to normal group and ${ }^{*} \mathrm{p}<0.05$, ${ }^{* * *} \mathrm{p}<0.001$ as compared to DMBA treated mice, BA: Bartogenic acid. The figure in the parenthesis indicates the dose in $\mathrm{mg} / \mathrm{kg}$ p.o.
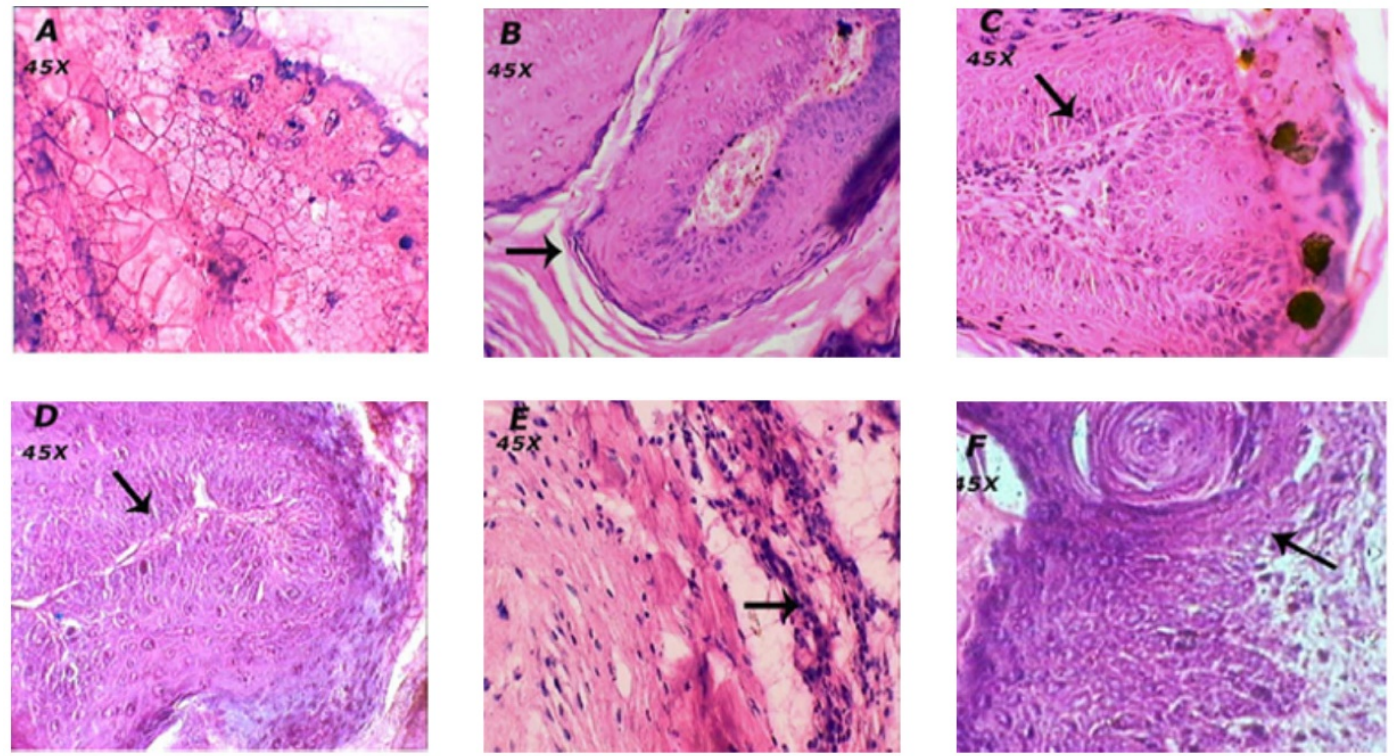

Figure 5. Effect of BA on histopathological alterations in skin tissue. Morphological variations in tumor appearance during DMBA/Croton oil induced skin carcinogenesis. A: Normal control or vehicle treated mice showed normal skin layers and structure; B: DMBA/Croton oil treated mice showed thickening of the epidermis, invasion of epidermal cells in the dermis, and formation of keratin pearls. The dermal region showedreduced dermal fibroblasts and fibroconnective tissues. C: BA ( $1 \mathrm{mg} / \mathrm{kg}$ p.o.) showed mild prevention of skin carcinogenesis as observed by decrease in the thickening of epidermal layer; D: BA ( $2 \mathrm{mg} / \mathrm{kg}$ p.o.) and E: BA (4 $\mathrm{mg} / \mathrm{kg}$ p.o.) showed normal structure and architecture of skin. F: Topical BA (4 mg/kg) mild to moderate prevention of skin carcinogenesis.

\section{Discussion}

The present study findings reveal that BA elicit selective cytotoxicity against the cutaneous squamous cell carcinoma cell line and markedly suppresses the initiation and progression phases of DMBA/Croton oil-induced two stage skin carcinogenesis by modulating the PhaseII detoxification enzyme and improving antioxidant defense.

The preclinical model of skin carcinogenesis induced in mice by application of DMBA/Croton oil 
involves three sequential steps of tumor initiation (conversion/neoplasia), promotion (propagation/ dysplasia or hyperplasia), and progression (metastatic). The appearance of papillomas primarily indicates the stage of carcinogenesis [19]. In present study, application of DMBA/Croton oil induced 100\% tumor incidence. However, treatment with BA showed dose dependent regression of two stage carcinogenesis. The effects observed in our study are in agreement with a previous report [20] showing chemotherapeutic efficacy of seed extracts of $B$. racemosa against anti-Dalton's Lymphoma Ascitic (DLA) cells. The activity of this extract was also found comparable to vincristine, a standard chemotherapeutic agent.

The reactive oxygen species (ROS) are implicated in the process of carcinogenesis [21]. The initiation and progression of tumor development and uncontrolled cell proliferation results from damaged or exhausted cellular apoptotic mechanisms [22]. The skin of the mice subjected to DMBA/Croton oil show an increase in the level of lipid peroxidation that is indicative of an overwhelming rise in the oxidative stress. Whereas, this raised lipid peroxidation product formation was markedly attenuated by the BA treatment in a dose dependent manner. In the present study, the antioxidant defense, both enzymatic antioxidants (SOD, CAT and GSHPx) and non-enzymatic (GSH) were found to be decreased in DMBA/Croton oil applied group. However, reduction in the levels of the GSH shows its increased consumption to counteract the elevated level of ROS. The chemopreventive effect observed in BA treated mice can be reasonably ascribed to its antioxidant action. These effects may be contributed to the pentacyclic triterpenoid nature of BA as this class of phytoconstituents possesses potent antioxidant and anti-inflammatory activities [24].

Glutathione S-transferase (GST) and GSH are elements of Phase II enzyme system, involved in the detoxification of xenobiotics and protection of cellular macromolecules from reactive electrophiles [25]. GST has regulatory role in the mitogen-activated protein kinase (MAPK) pathway through which it can modulate cellular survival and death signals via protein: protein interactions with c-Jun N-terminal kinase 1 (JNK1) and ASK1 (apoptosis signal-regulating kinase). In the present study, we found that GST activity and GSH levels were significantly decreased in the skin tissues of DMBA/Croton oil-induced mice. BA treatment reversed these alterations in GST and GSH indicating that its chemopreventive activity involves enhanced detoxification of oxidative radicals generated as a consequence of DMBA/Croton oil application. Thus, the observed antioxidant activity of BA may contribute to the prevention of the DNA adduct formation by activating GST and enhancing enzymatic antioxidants.

The antioxidant enzymes, especially SOD and catalase reduce tumorigenesis both in vitro and in vivo [26]. SOD and catalase play a key role in the detoxification of superoxide anion and hydrogen peroxide, respectively. BA treatment significantly increased the activities of SOD and CAT that correlates with chemoprevention against DMBA/Croton oil-induced carcinogenesis. Furthermore, lipid peroxidation which is a self-propagating free radical chain reaction leads to loss of biochemical and structural architecture of cellular organelles was found dose dependently decreased in BA treated animals.

BA has potent anti-inflammatory activity and anti-arthritic activity in Complete Freund's Adjuvant (CFA)-induced arthritis in rats via some degree of immunomodulation [11]. Increased oxidative stress induced by the free radicals from activated immune cells plays an important role in the inflammation-induced cancer [27]. Inflammation aids in the proliferation and survival of malignant cells [28]. BA treatment may provide possible protection against chronic inflammatory condition which is well evident in chemically induced carcinogenesis. Furthermore, possible immunomodulation by BA is proposed to be involved in the inhibition of carcinogenesis observed in the present study. In an earlier study, BA was found to reduce complete Freund's adjuvant (CFA) induced rise in the C-reactive protein (CRP) in rats [11]. CRP is an inflammatory acute-phase protein that serves as a marker for systemic inflammation. The rise in CRP is observed during many types of solid cancers and is considered as an important biomarker for the prediction of the outcome of different cancerous conditions and shows a causative relation with cancer. In the present study, CRP levels were not estimated. However, correlating with this property, we speculate that the chemopreventive effect of BA observed in this study may be related to its capacity to attenuate elevated circulatory CRP level.

Recently, BA is reported to possess alpha glucosidase inhibitory activity [29]. Alpha glucosidase is proposed to be involved in the cellular interactions with collagen type-I and IV and has a role in tumor metastasis [30]. In present study, we did not determine the effect of BA on alpha glucosidase or its role in chemoprevention. However, the involvement of alpha glucosidase inhibitory efficacy of BA in the observed chemoprevention is also predicted. The mechanism of action can be multimodal as it has 
potential to modulate mediators of inflammation and oxidative stress that play an important role in causation of skin cancer. Taken together, the present study demonstrates that BA elicit chemopreventive action however the mechanism is not yet elucidated and need to be investigated.

\section{Conclusion}

Based on findings, it can be concluded that BA possess chemopreventive potential and anti-proliferative activity against cutaneous squamous cells by inhibiting carcinogenesis in DMBA/Croton oil-induced mice model via up regulation of enzymatic and non-enzymatic antioxidants. It is noteworthy that BA exerts these effects at oral doses ranging from $1-4 \mathrm{mg} / \mathrm{kg}$.

Our results emphasize that there is a need of further investigation to delineate the molecular mechanisms of antitumor and anti-proliferative activity of BA. Apart from the oxidative stress, other mechanisms like NF-kB pathway activation and related mutations are involved in the DMBA/Croton oil carcinogenesis. Systematic exploration of the alterations in these molecular pathways is warranted to elucidate the exact mechanism of action of the BA as a chemopreventive agent.

\section{Acknowledgment}

The authors gratefully acknowledge the infrastructure support to Prof. C. R. Patil \& Sameer Goyal from RCPIPER, Maharashtra, India and the research support to Shreesh Ojha from United Arab Emirates University, United Arab Emirates.

\section{Conflict of Interests}

The author(s) declared no potential conflicts of interest with respect to the research, authorship, and/or publication of this article.

\section{References}

1. World Health Organisation. World cancer report, 2014. WHO Report Geneva: WHO. 2014.

2. Macheret M, Halazonetis TD. DNA Replication Stress as a Hallmark of Cancer. Annual Review of Pathology: Mechanisms of Disease 2015; 10: 425-48.

3. Sharma J, Singh R, Goyal P. Chemomodulatory potential of flaxseed oil against DMBA/croton oil-induced skin carcinogenesis in mice. Integrative cancer therapies. 2015: 1534735415608944.

4. Ra H, González-González E, Uddin MJ, et al. Detection of Non-melanoma skin cancer by in vivo fluorescence imaging with fluorocoxib A. Neoplasia 2015; 17: 201-7.

5. Manoharan S, Selvan MV. Chemopreventive potential of geraniol in 7, 12-dimethylbenz (a) anthracene (DMBA) induced skin carcinogenesis in Swiss albino mice. 2012.

6. Saha D, Hait M. An ontological design: two stage mouse skin carcinogenesis induced by DMBA and promoted by croton oil. Asian Journal of Research in Pharmaceutical Sciences 2012; 2: 1-3.

7. Abel EL, Angel JM, Kiguchi K, et al. Multi-stage chemical carcinogenesis in mouse skin: fundamentals and applications. Nature protocols 2009; 4: 1350-62.

8. Thomas TJ, Panikkar B, Subramoniam A, et al. Antitumour property and toxicity of Barringtonia racemosa Roxb seed extract in mice. Journal of ethnopharmacology 2002; 82: 223-7.
9. Gowri PM, Radhakrishnan S, Basha SJ, et al. Oleanane-type isomeric triterpenoids from Barringtonia racemosa. Journal of natural products 2009; 72: 791-5.

10. Khan S, Jabbar A, Hasan C, Rashid M. Antibacterial activity of Barringtonia racemosa. Fitoterapia 2001; 72: 162-4.

11. Patil KR, Patil CR, Jadhav RB, et al.. Anti-arthritic activity of bartogenic acid isolated from fruits of Barringtonia racemosa Roxb.(Lecythidaceae). Evidence-Based Complementary and Alternative Medicine 2011; 2011.

12. Qiblawi S, Al-Hazimi A, Al-Mogbel M, et al. Chemopreventive effects of cardamom (Elettaria cardamomum L.) on chemically induced skin carcinogenesis in Swiss albino mice. Journal of medicinal food 2012; 15: 576-80.

13. Maqbool M, Vidyadaran S, George E, Ramasamy R. Optimisation of laboratory procedures for isolating human peripheral blood derived neutrophils. Medical Journal of Malaysia 2011; 66: 297.

14. Majed F, Rashid S, Khan AQ, et al. Tannic acid mitigates the DMBA/croton oil-induced skin cancer progression in mice. Molecular and cellular biochemistry 2015; 399(1-2): 217-228.

15. Hou H, Li B, Zhao X, Zhuang Y, Ren G, Yan M, et al. The effect of pacific cod (Gadus macrocephalus) skin gelatin polypeptides on UV radiation-induced skin photoaging in ICR mice. Food chemistry 2009; 115: 945-50.

16. Divya MK, Salini S, Meera N, et al. Attenuation of DMBA/croton oil induced mouse skin papilloma by Apodytes dimidiata mediated by its antioxidant and antimutagenic potential. Pharmaceutical biology 2016; 1-11.

17. Saleem M, Naseer F, Hussain K. Cytotoxic effect of methanol extract of Conyza bonariensis on DMBA-induced skin carcinogenesis: An in vivo study. Bangladesh Journal of Pharmacology 2015; 10(2): 467-474

18. Sharma J, Singh R,Goyal PK. Chemomodulatory Potential of Flaxseed Oil Against DMBA/Croton Oil-Induced Skin Carcinogenesis in Mice. Integrative Cancer Therapies, 2015; 1534735415608944

19. Das I, Saha T. Effect of garlic on lipid peroxidation and antioxidation enzymes in DMBA-induced skin carcinoma. Nutrition 2009; 25(4): 459-471.

20. Thomas TJ, Panikkar B, Subramoniam A et al. Antitumour property and toxicity of Barringtonia racemosa Roxb seed extract in mice. Journal of Ethnopharmacology 2002; 82(2); 223-227

21. Li X, Fang P, Mai J, Choi ET, Wang H, Yang X. Targeting mitochondrial reactive oxygen species as novel therapy for inflammatory diseases and cancers. Journal of Hematology and Oncology 2013; 6: 19.

22. Hanahan D, Weinberg RA. Hallmarks of cancer: the next generation. Cell 2011; 144: 646-74

23. Liby KT, Yore MM, Sporn MB. Triterpenoids and rexinoids as multifunctional agents for the prevention and treatment of cancer. Nature Reviews Cancer 2007; 7: 357-69.

24. Townsend DM, Tew KD. The role of glutathione-S-transferase in anti-cancer drug resistance. Oncogene 2003; 22: 7369-75.

25. Song X, Liu BC, Lu XY et al. Lovastatin inhibits human B lymphoma cell proliferation by reducing intracellular ROS and TRPC6 expression. Biochimica et Biophysica Acta (BBA)-Molecular Cell Research 2014; 1843: 894-901.

26. Valavanidis A, Vlachogianni T, Fiotakis K, Loridas S. Pulmonary oxidative stress, inflammation and cancer: respirable particulate matter, fibrous dusts and ozone as major causes of lung carcinogenesis through reactive oxygen species mechanisms. International Journal of Environmental Research and Public Health 2013; 10: 3886-907.

27. Balkwill FR, Mantovani A. Cancer-related inflammation: common themes and therapeutic opportunities. Seminars in cancer biology 2012;: 33-40.

28. Allin $\mathrm{KH}$, Nordestgaard BG. Elevated C-reactive protein in the diagnosis, prognosis, and cause of cancer. Critical Reviews in Clinical Laboratory Sciences 2011; 48: 155-70.

29. Gowri PM, Tiwari AK, Ali AZ, Rao JM. Inhibition of a-glucosidase and amylase by bartogenic acid isolated from Barringtonia racemosa Roxb. seeds. Phytotherapy Research 2007; 21: 796-9.

30. Benalla W, Bellahcen S, Bnouham M. Antidiabetic medicinal plants as a source of alpha glucosidase inhibitors. Current Diabetes Reviews 2010; 6(4): 247-254. 